\title{
Influence of physical and chemical factors on settlement and recruitment of the hydroid Tubularia larynx
}

\author{
Pierre Nellis, Edwin Bourget* \\ GIROQ, Département de Biologie, Université Laval Québec, Québec, Canada G1K 7P4
}

\begin{abstract}
Field observations using settlement panels, which were carried out in Port Daniel Bay, Baie des Chaleurs, Québec, Canada, in 1992, showed recruitment by the hydroid Tubularia larynx to be unevenly distributed with depth. Multiple regression on residuals indicated that 2 physical factors, water temperature and light intensity, out of 5 tested explained $45 \%$ of the observed variance in the recruitment of $T$. larynx on the panels. In laboratory experiments, warm temperatures increased settlement significantly. Contrary to field results, light intensity did not seem to influence the settlement of T. Iarynx in the laboratory. The influence of small scale $(<\mathrm{mm})$ substrate heterogeneity was also tested in the laboratory. Highest settlement rates occurred on smooth surfaces, but field experiments carried out in 1993 did not show any heterogeneity preference by $T$ larynx. The influence of extracts and metabolites of conspecific adults on larval settlement was also tested in the laboratory and field. Adult extracts had some influence on settlement in some laboratory trials, but not in others. In general, $T$ larynx settled more abundantly on surfaces treated with high concentrations of extract solutions than on other surfaces. As was the case for substratum heterogeneity, there was no influence of adult extracts detected in the field. In contrast, adult metabolites showed little influence on settlement under laboratory conditions and no influence on recruitment in field experiments
\end{abstract}

KEY WORDS: Hydroid Tubularia larynx - Settlement Recruitment - Physical factors - Biochemical factors

\section{INTRODUCTION}

For many sessile marine invertebrates, the transition between pelagic and sessile forms is a critical stage in their life cycle (Crisp 1984, Bourget 1988). This phase is important not only because of the associated physiological and morphological changes, but also because the selection of a suitable settlement site by a larva will influence the rest of the subsequent success of the individual throughout its juvenile and adult stages. The choice of a given microhabitat at settlement should be appropriate, since for many species the process is irreversible. Settlement rates have been found to be influenced by passive (Butman 1987, Eckman 1987, Mullineaux \& Butman 1991, Harvey et al. 1995) and active processes (Crisp 1974, Butman et al. 1988, Bourget

-Addressee for correspondence.

E-mail: edwin.bourget@giroq.ulaval.ca
1988, Pawlik 1992). The former are associated with hydrodynamic conditions and involve the passive dispersion and deposition of larvae (Butman 1987, Pawlik 1992). The latter usually refer to larval behaviour which results in an active choice of microhabitat using environmental cues (Butman 1987, Bourget 1988, Pawlik 1992). Recent models of larval settlement have proposed that passive processes dominate over large spatial scales $(>m)$ and active choice is important over smaller spatial scales $(<\mathrm{m})$ (see Bourget 1988, Butman \& Grassle 1992, Grassle et al. 1992, Boudreau et al. 1993a). This dichotomy, however, is not necessarily as exclusive as assumed in the past (Boudreau et al. 1993a).

Factors which influence the exploration and selection of a settlement site may be divided into 2 types. The first consist of environmental factors such as light, gravity, hydrostatic pressure, current velocity, temperature, salinity, and substrate heterogeneity and com- 
plexity (Thorson 1964, Crisp 1974, Butman 1987. Young \& Chia 1987, Bourget 1988, Boudreau et al. 1990, Butman \& Grassle 1992). The second consists of biological factors associated with the colonizing organisms, for example, larval competence and biochemical inducers (Crisp \& Meadows 1963, Crisp 1984, Chabot \& Bourget 1988, Bonar et al. 1990, Pawlik 1992, Rodríguez et al. 1993).

Settlement-inducing substances often originate from conspecifics, as in the case of barnacles (Knight-Jones 1953. Crisp \& Meadows 1963, Chabot \& Bourget 1988), molluscs (Bonar et al. 1990), echinoderms (Pearce \& Scheibling 1990) and ascidians (Svane et al. 1987). However, for other species the settlement-inducing substances may be prey species (Prenant \& Tessier 1924, Hadfield 1984, Yund et al. 1987, BahamondesRojas 1988, Llobet et al. 1991) or microbial films consisting of diatoms, cyanobacteria or bacteria on the substrate (Schmahl 1985, Butman 1987, Johnson et al. 1991, Rodríguez et al. 1993). Other organisms are deterred from settling by cues emitted by a predator: for example, Homarus americanus larvae avoid extracts and metabolites of Tautogolabrus adspersus, a fish predator (Boudreau et al. 1993a, b), or a strong interspecific competitor (Young \& Chia 1987). Other species prevent fouling by releasing a specific cue (Sieburth \& Conover 1965, Davis \& Wright 1989), while others appear to prevent larvae from settling on the adult stage with an overabundance of a particular cue (Rittschof et al. 1984, Chabot \& Bourget 1988).

Hydrozoa are one of the early metazoan colonizers of virgin substrata (Dean \& Hurd 1980) and are important foulers (Crisp 1984). They are also selected preferentially by scallop larvae at settlement (Harvey et al. 1993) and are therefore important in the settlement process of these commercial species. Thus, using hydroids as collectors of scallop spat is potentially possible providing the settlement process could be understood and managed adequately. In addition, among the studies which examined hydrozoan ecology (Pyefinch \& Downing 1.949, Hawes 1958, Williams 1965, 1976, Hughes 1977, 1983, 1986, 1987, Sutherland \& Karlson 1977. Hughes \& Henderson 1989) few have focussed on the settlement process, particularly for the genus Tubularia.

The actinula, the settlement stage of the genus Tubularia, is not a larvae in the proper sense, but a small juvenile polyp. Since there is no reason a priori to believe that its site selec. tion process would differ substantially from that of the larvae of other invertebrates, the present study examined the sensitivity of $T$. larynx actinulae, both in situ and in the laboratory, to physical factors and potential biochemical cues likely to influence settlement and recruitment (sensu Connell 1985). Physical factors examined included depth, temperature, light and substrate heterogeneity. In addition, the settlement response of actinulae was measured after the addition of a variety of biologically derived substances. As well as testing the influence of the adult metabolites and extracts of $T$ larynx, we examined the effect of potential prey extracts (zooplankton) and predator extracts from Cancer irroratus, Strongylocentrotus droebachiensis and Dendronotus frondosus on the settlement processes. Several studies have shown a positive response by hydrozoans to algal extracts (Nishihiria 1967, 1968, Katô et al. 1975). We examined the effect of extracts from benthic diatoms and from 3 macroalgae, Ulva lactuca, Palmaria palmata and Laminaria digitata.

\section{METHODS}

Site and field observation studies. Field studies were conducted in Port Daniel Bay (Fig 1), Baie des Chaleurs, Québec, Canada in 1992 and 1993. Between 31 August and 12 October 1992 (42 d) and 11 June and 8 August 1993 (58 d) collectors were placed at 2 locations to determine the maximum recruitment depth for Tubularia larynx. Each collector consisted of 5 PVC (polyviny] chloride) panels $(30.5 \times 25.5 \times 0.6 \mathrm{~cm})$ at 5 depths $(2,7,12,17$ and $22 \mathrm{~m})$ in a $24 \mathrm{~m}$ water column. On each panel, 5 microscope glass slides $(75 \times 25 \times$ $1 \mathrm{~mm}$ ) were attached in a vertical position with 2 plastic screws. After the end of the experiment the wet mass of $T$ larynx colonies and other species on the microscope slides was measured using an analytical balance (Mettler model PE 360, $\pm 0.0005 \mathrm{~g}$ ).

In 1992, 6 temperature and salinity profiles were recorded using a Sea Bird CTD probe (model Sealog-

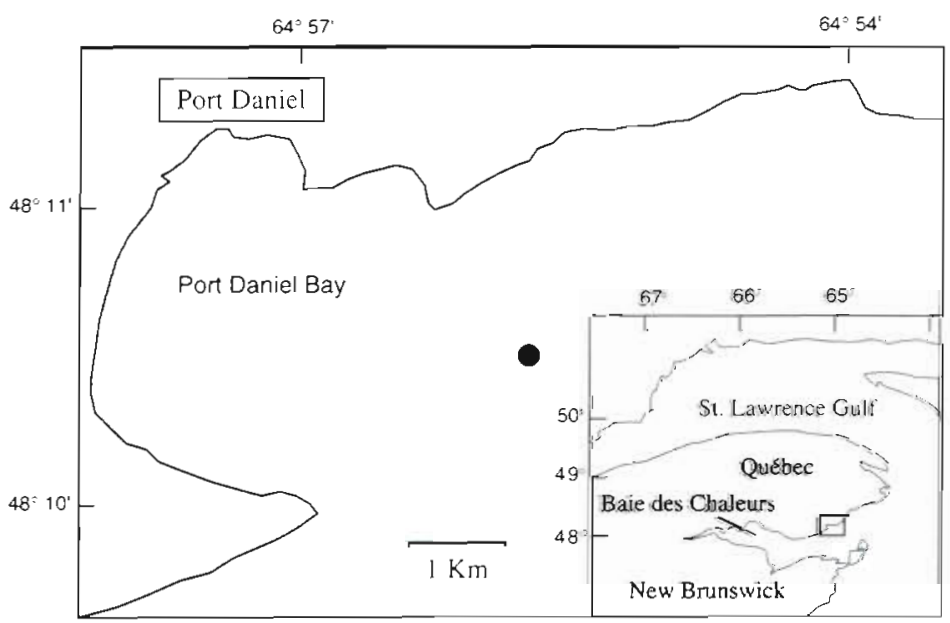

Fig. 1 Location of the field study site $(1)$ in Port Daniel Bay, Baie des Chaleurs, Québec, Canada 
ger SBE-19) and fluorescence profiles were recorded with a Sea Tech fluorometer. Quantum irradiance was measured using a photometer (Biospherical Instrument Co., model $4 \pi$ QSP-200 sensor connected to a QSP$170 \mathrm{~B}$ integrating meter). In 1992, irradiance at each sampling depth was estimated from an irradiance curve calculated from data collected on 4 occasions ( 7 , 10,13 and 18 August) at 3 depths $(0,5$ and $10 \mathrm{~m})$. In 1993, 11 measurement series of temperature, salinity and current velocity were taken at the same depths as the 5 collectors using S4 InterOcean current meters at 10 min intervals. In 1993 irradiance was measured at the 5 depths on $21 \mathrm{~d}$ during the experimental period.

Field experiments. General procedures: The effect of substrate heterogeneity, hydroid extracts and metabolites, and extracts from other organisms on Tubularia larynx recruitment were tested in the field. The experiments were carried out in Port Daniel Bay (Fig. 1) between 4 August and 10 October 1993. Collectors were constructed from PVC panels with 25 glass microscope slides per panel. The panels were submerged at a depth of $12 \mathrm{~m}$ in a $24 \mathrm{~m}$ water column. The $T$. larynx used to prepare extracts and obtain metabolites for these experiments were collected on mooring lines on 3 August. The remaining organisms used to make test solutions (Table 1) were collected on 19 August. Macroalgae and predators were collected at a depth of $4 \mathrm{~m}$ using SCUBA. Zooplankton were collected from a depth of $4 \mathrm{~m}$ using a $150 \mu \mathrm{m}$ plankton net. Diatoms were collected by scraping a nearby buoy. The protocol employed to prepare extracts and metabolites is decribed below in the section 'Preparation of extract and metabolite solutions' (see also
Table 1). At the end of each experiment, the weight of $T$. larynx colonies present on microscope slides was measured after drying to constant mass at $70^{\circ} \mathrm{C}$ for $72 \mathrm{~h}$ with a Mettler analytical balance.

Preparation of extract and metabolite solutions: Test solutions were prepared from freshly collected material. To make extracts of Tubularia larynx, tissues were homogenized in a blender for 2 min with $0.45 \mu \mathrm{m}$ membrane filtered sea water (see Table 1 for ratios between organisms and volume of sea water). The resulting homogenate was centrifuged at $3000 \times g$ for $30 \mathrm{~min}$. The supernatant was filtered using Whatman $\mathrm{GF} / \mathrm{C}$ filters. This protocol is analogous to that used for cirripedes (Crisp \& Meadows 1962) and for ascidians (Svane et al. 1987, Havenhand \& Svane 1991). For $T$. larynx metabolites, an aliquot of $500 \mathrm{ml}$ of water (see Table 1) was filtered onto Whatman GF/C filters. This method was similar to that used by Boudreau et al. (1993b) to obtain metabolites of mussels. Dilutions of the initial solution $(0.1,1$ or $10 \%)$ for $T$. larynx extracts and metabolites were made using filtered sea water (Whatman GF/C). A fresh extract or metabolite solution was used for each experiment. Petri dishes $(100 \times$ $15 \mathrm{~mm}$ ) and microscope slides were treated with $0.2 \mathrm{ml}$ of extracts, metabolites or $0.45 \mu \mathrm{m}$ filtered sea water which was applied with a small brush and then air dried for $2 \mathrm{~h}$. A new brush was used for each treatment. All materials were cleaned after each experiment with a solution of sodium hypochlorite $(5.25 \%)$ and rinsed thoroughly with filtered water.

Influence of Tubularia larynx extracts and metabolites on recruitment: Between 5 August and 10 October 1993, 2 experimental collectors were submerged to

Table 1. Ratio between organism wet mass and the volume of sea water used to obtain test solutions. Material collected at the field study site, near Port Daniel, Baie des Chaleurs, Canada

\begin{tabular}{|c|c|}
\hline Test solutions & Preparation ratio \\
\hline \multicolumn{2}{|l|}{ Animals } \\
\hline Tubularia larynx (extracts) & $100 \mathrm{~g}$ (wet mass) of adult homogenized in $50 \mathrm{ml}$ of filtered sea water \\
\hline Tubularia larynx (metabolites) & $\begin{array}{l}\text { Aliquot of water from a } 11 \text { glass jar in which living adults (100 g wet mass) } \\
\text { maintained for } 24 \mathrm{~h}\end{array}$ \\
\hline Cancer irroratus (extracts) & $15 \mathrm{~g}$ (wet mass) of common rock crab homogenized in $15 \mathrm{ml}$ of filtered sea \\
\hline $\begin{array}{l}\text { Strongylocentrotus droebachiensis } \\
\text { (extracts) }\end{array}$ & $15 \mathrm{~g}$ (wet mass) of green sea urchin homogenized in $60 \mathrm{ml}$ of filtered sea wo \\
\hline Dendronotus frondosus (extracts) & $20 \mathrm{~g}$ (wet mass) of nudibranch homogenized in $20 \mathrm{ml}$ of filtered sea water \\
\hline Zooplankton, i.e. Crustacea (extracts) & $\begin{array}{l}20 \mathrm{~g} \text { (wet mass) of zooplankton, i.e. Crustacea (Pseudocalanus minutus elon } \\
\text { Eurytemora sp., Calanus finmarchicus, Calanus glacialis, Temora longicorn } \\
\text { Oithona similis, Podon leuckarti, Evadne sp., Centropages hamatus, bivalve } \\
\text { copepod nauplii, Euphausiacea) homogenjzed in } 40 \mathrm{ml} \text { of filtered sea water }\end{array}$ \\
\hline \multicolumn{2}{|r|}{ 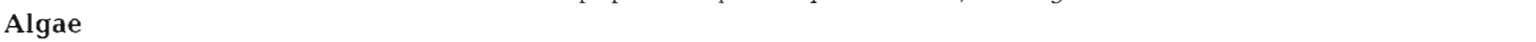 } \\
\hline Ulva lactuca (extracts) & $15 \mathrm{~g}$ (wet mass) of green algae homogenized in $60 \mathrm{ml}$ of filtered sea water \\
\hline Laminaria digitata (extracts) & $20 \mathrm{~g}$ (wet mass) of kelp homogenized in $40 \mathrm{ml}$ filtered sea water \\
\hline Palmaria palmata (extracts) & $12 \mathrm{~g}$ (wet mass) of red algae homogenized in $48 \mathrm{ml}$ of filtered sea water \\
\hline Diatoms (extracts) & $16 \mathrm{~g}$ (wet mass) of diatoms homogenized in $64 \mathrm{ml}$ of filtered sea water \\
\hline
\end{tabular}




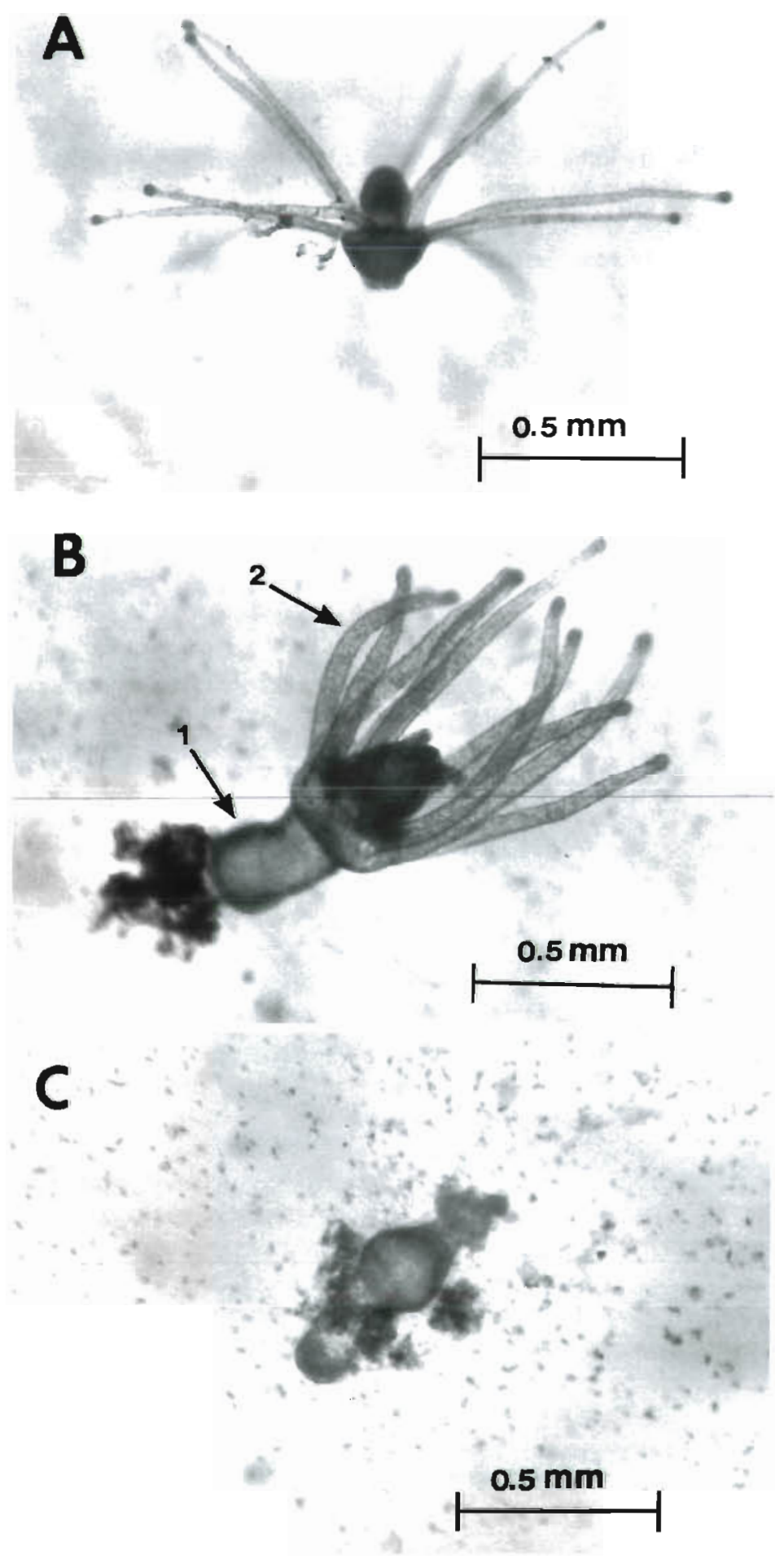

Fig. 2. Tubulana larynx. (A) Free actinula, (B) settled actinula (72 h), and $(C)$ damaged settled actinula $(72 \mathrm{~h}) .1$ : aboral pole (elongated); 2: aboral tentacles determine the influence of adult extracts on recruitment of $T$ larynx. Half of the microscope slides were treated with an adult extract solution at $100 \%$ concentration (Table 1 ) and the other half with $0.45 \mu \mathrm{m}$ filtered sea water (see section above). The microscope slides were placed randomly on the 2 collectors (Buoys A and B) and the collectors suspended to a depth of $12 \mathrm{~m}$. The same procedure was used to examine the effects of metabolite solutions on recruitment with adult hydroids used for metabolite solutions collected on 3 August. This experiment was carried out between 4 August and 10 October 1993.

Influence of substratum heterogeneity on recruitment: This experiment was carried out to test: (1) the influence of substrate heterogeneity on Tubularia larynx recruitment; and (2) the influence of the location of microscope slides on collectors. Sand-coated microscope slides were prepared by fixing calibrated sand grains onto slides using a nontoxic epoxy resin (Lepage Inc.). Five sand-coated microscope slides per heterogeneity class $(5$ classes: 1000 , $500,250,0 \mu \mathrm{m}$ and control) were placed on an experimental collector in a Latin square design. Two replicates of this arrangement were moored on separate lines between 12 August and 10 October 1993.

Influence of extracts of different species on recruitment: Eight different types of extract solutions (Table 1) and 1 filtered sea water control solution were applied to microscope slides. These were left to air dry for at least $2 \mathrm{~h}$. Ten slides were treated with each type of extract ( $N=80$ ) and 20 with filtered sea water $(\mathrm{N}=20)$. The treated and control slides were placed randomly on 4 experimental collectors which were left at $12 \mathrm{~m}$ depth from 19 August until 10 October 1993.

Laboratory experiments. General procedures: Laboratory experiments were carried out in September and October 1993. To obtain actinulae (Fig 2A), mature colonies of Tubularia larynx were collected daily from a mooring line which had been submerged in the Bay for 3 mo prior to the beginning of the experiments. These colonies were suspended, polyps downward, for $6 \mathrm{~h}$ in fresh sea water in the dark in a refrigerator at $10^{\circ} \mathrm{C}$ (see Pyefinch \& Downing 1949). This method is known to facilitate actinula release. Actinulae were counted under a stereomicroscope, collected using a pipette and normally 25 individuals, unless otherwise stated, were placed in Petri 
dishes $(100 \times 15 \mathrm{~mm})$ filled with $40 \mathrm{ml}$ of sea water. Only undamaged actinulae (not planulae) were used in the experiments. Actinulae were considered to have settled when they were attached to the Petri dish by the aboral pole and the tentacles were free of the substrate (Fig. 2B; Hawes 1958). The sea water used in laboratory experiments was collected daily from the field site with a $10 \mathrm{l}$ Niskin bottle from $12 \mathrm{~m}$ and filtered through Whatman GF/C filters $(1.2 \mu \mathrm{m})$. Based on preliminary observations in 1992, the experiments were extended over $72 \mathrm{~h}$ (see also Pyefinch \& Downing 1949 and Hawes 1958). The percentage of damaged settled individuals was recorded at the end of the experiments (see Fig. 2C) to examine any treatment effect on actinula condition. Unless indicated otherwise all settlement trials were carried out in a dark refrigerator set at a specified temperature.

Expt A: Influence of temperature: To test the influence of temperature on settlement, replicates of 4 Petri dishes, each containing 25 actinulae in $40 \mathrm{ml}$ of filtered sea water, were placed into refrigerators set at 5,10 and $15^{\circ} \mathrm{C}\left( \pm 0.5^{\circ} \mathrm{C}\right)$. These experiments were carried out in darkness and the Petri dishes were left undisturbed over the $72 \mathrm{~h}$ period. Four trials of this experiment were made over a period of $6 \mathrm{~d}$, between 1 and 7 September.

Expt B: Influence of light intensity: The effect of different light levels on settlement was examined at 6 irradiance levels, nominally 500, 100, 25, 5, 2 and $0 \mu$ Ein $\mathrm{m}^{-2} \mathrm{~s}^{-1}$ The light was from a $400 \mathrm{~W}$ Optimac high pressure sodium lamp. The light level was adjusted by changing the distance between the lamp and the dishes. Actual light levels were measured before and after each experiment at 3 points in each Petri dish. Actual light levels were $( \pm \mathrm{SE}): 490.18( \pm 43.94)$, $96.68( \pm 6.11), 24.08( \pm 2.36), 5.68( \pm 0.44), 2.06( \pm 0.18)$ and $0 \mu$ Ein $\mathrm{m}^{-2} \mathrm{~s}^{-1}$. For this experiment, the 3 replicate Petri dishes per treatment were placed in an incubator at $10^{\circ} \mathrm{C}\left( \pm 0.05^{\circ} \mathrm{C}\right)$ equipped with a circulating water bath (Haake model $G$ Fisions). Four trials were made over a period of $8 \mathrm{~d}$, between 14 and 27 September.

Expt C: Influence of substratum heterogeneity. Experiment without choice: Four classes of substrate heterogeneity were created by fixing calibrated sand grains (commercially used for sand blasting and devoid of non-mineral components) to Petri dishes using a nontoxic epoxy resin. Five Petri dishes were coated with sand from each of the following size categories ( $\mu \mathrm{m})$ : 1200 to $1000(1000), 830$ to 500 (500), 350 to 250 (250), 0 (with epoxy resin only, Control I). Another control (Control II, no sand and no glue) was added for this experiment which resulted in a total of 25 dishes. All Petri dishes were placed at random in a refrigerator at $10^{\circ} \mathrm{C}\left( \pm 0.5^{\circ} \mathrm{C}\right)$ for $72 \mathrm{~h}$. This experiment was begun out on 2 October.
Expt D: Influence of substrate heterogeneity. Experiment with choice: For this experiment, the Petri dishes were divided into halves. One half was coated with a nominal size grain sand, 1000,500, 250, or $0 \mu \mathrm{m}$ (epoxy coat without sand). The other half was used as a control and kept untreated. Five replicate dishes were used for each class of heterogeneity/control combination and placed at random in the dark at $10^{\circ} \mathrm{C}$ $\left( \pm 0.5^{\circ} \mathrm{C}\right)$. A total of 6 trials were carried out between 14 and 29 September. For the first 3 trials (1, 2 and 3 ) each Petri dish contained 25 actinula as usual and for the last 3 (4,5 and 6), 50 actinula were used in each Petri dish.

Expts $E$ and F: Influence of adult Tubularia larynx metabolites (E) and extracts (F). Experiments without choice: The purpose of these experiments was to test the influence of different concentrations of extracts or metabolites on actinulae settlement. Petri dishes were lightly coated (1 coat) with extracts of adult Tubularia larynx. Five replicate dishes were used for each extract concentration $(100,10,1$ or $0.1 \%)$ and 20 for controls (filtered sea water with no extract, or $0 \%$ ). Dishes were placed randomly in darkness at $10^{\circ} \mathrm{C}\left( \pm 0.5^{\circ} \mathrm{C}\right)$ for $72 \mathrm{~h}$. Three trials of this experiment were carried out over a period of $9 \mathrm{~d}$, between 23 September and 2 October. The same experimental protocol was used to examine the effect of $T$. larynx metabolites on settlement. Those experiments were carried out between 24 September and 2 October.

Expts $G$ and H: Influence of adult Tubularia larynx metabolites $(G)$ and extracts $(H)$. Experiments with choice: In the following experiments, we tested: (1) the influence of 4 concentrations of extracts of Tubularia larynx on actinula settlement; and (2) whether if given a choice, actinulae preferred treated or untreated surfaces for settlement. Each Petri dish used in these experiments was divided into 2 parts. Half of each dish was treated with 1 of 4 concentrations while the other half was treated with filtered sea water. The Petri dishes, 5 for each extract/sea water combination $(\mathrm{N}=$ $20)$, were placed at random in the dark at $10^{\circ} \mathrm{C}$ $\left( \pm 0.5^{\circ} \mathrm{C}\right)$. For the first 3 trials $(1,2$ and 3$)$, each Petri dish contained 25 actinula and for the last 3 (4, 5 and 6), each dish contained 50 actinula in $40 \mathrm{ml}$ filtered sea water. These trials were conducted between 14 and 27 September. The same experimental protocol was used to test the influence of metabolites on settlement; those trials were carried out between 19 September and 3 October.

Statistical analysis. All statistical analyses were carried out using the SAS/STAT (SAS Institute Inc. 1991) statistical computer program.

Field observation studies: Statistical analyses were carried out on square root transformed data to meet the assumptions of normality and homoscedasticity of 
Table 2. Summary of environmental data recorded at Port Daniel in 1992 and 1993 and wet mass of other species not including Tubularia larynx on collectors. Values are averages $( \pm \mathrm{SD})$ for the period of field studies. For temperature, salinity and fluorescence in 1992, $N=6$ per depth; irradiance in 1992 was estimated from an irradiance curve calculated from data collected during 4 days at 3 depths $(0,5$ and $10 \mathrm{~m})$. In 1993, $N=11$ per depth for temperature, salinity and current velocity, and $N=21$ per depth for irradiance. Dashes indicate no available data

\begin{tabular}{|c|c|c|c|c|c|c|}
\hline $\begin{array}{l}\text { Depth } \\
(\mathrm{m})\end{array}$ & $\begin{array}{c}\text { Temperature } \\
\left.\qquad{ }^{\circ} \mathrm{C}\right)\end{array}$ & $\begin{array}{l}\text { Salınity } \\
(\%)\end{array}$ & $\begin{array}{c}\text { Irradiance } \\
\left(\mu \text { Ein } \mathrm{m}^{-2} \mathrm{~s}^{-1}\right)\end{array}$ & $\begin{array}{l}\text { Fluorescence } \\
\text { (arbitrary units) }\end{array}$ & $\begin{array}{l}\text { Mean current } \\
\text { velocity }\left(\mathrm{cm} \mathrm{s}^{-1}\right)\end{array}$ & $\begin{array}{l}\text { Wet mass of } \\
\text { other species }(g)\end{array}$ \\
\hline \multicolumn{7}{|c|}{1992 (31 August to 12 October) } \\
\hline 2 & $10.55(1.81)$ & $28.93(0.53)$ & 632.38 & $1.60(0.98)$ & - & $0.288(0.086)$ \\
\hline 7 & $9.31(1.44)$ & $29.31(0.42)$ & 227.00 & $1.73(1.21)$ & - & $0.197(0.106)$ \\
\hline 12 & $8.70(1.37)$ & $29.43(0.47)$ & 143.38 & $1.21(0.84)$ & - & $0.080(0.061)$ \\
\hline 17 & $6.79\{1.97\}$ & $30.08(0.82)$ & 91.51 & $0.83(0.60)$ & - & $0.470(1.293)$ \\
\hline 22 & $4.47(2.98)$ & $30.70(0.87)$ & 57.13 & $0.76(0.71)$ & - & $0.102(0.265)$ \\
\hline \multicolumn{7}{|c|}{1993 (11 June to 8 August) } \\
\hline 2 & $15.42(1.69)$ & $26.25(1.29)$ & $383.00(259.76)$ & - & $11.26(9.30)$ & $1.070(0.410)$ \\
\hline 7 & $13.60(2.40)$ & $26.90(1.19)$ & $88.60(55.02)$ & - & $10.71(5.28)$ & $0.641(0.228)$ \\
\hline 12 & $10.79(1.89)$ & $27.84(0.71)$ & $25.58(15.31)$ & - & $9.76(5.13)$ & $0.486(0.291)$ \\
\hline 17 & $9.20(1.52)$ & $28.27(0.66)$ & $7.38(4.89)$ & - & $12.95(7.67)$ & $0.261(0.174)$ \\
\hline 22 & $7.54(2.16)$ & $28.78(0.61)$ & $2.12(1.26\}$ & - & $11.81(7.35\}$ & $0.132(0.055)$ \\
\hline
\end{tabular}

residuals. Initially, the influence of depth on recruitment of Tubularia larynx was examined. For 1992, results were analysed using a randomized complete block design (Milliken \& Johnson 1992), followed by multiple pairwise comparisons tests of least squares means (LSMeans, see SAS Institute 1991) using Bonferroni's correction. For 1993, no statistical analysis was carried out since too few individuals were recruited on the microscope slides. Secondly, multiple regression was carried out on the 1992 field data to determine the relative effect on the recruitment of $T$. larynx by various physical factors and the biomass of the other species which were present on the collectors (see Table 2). Given that depth significantly influenced $T$. larynx abundance (see 'Depth of maximum recruitment'), and that all physical factors were correlated with depth, its effect on variation was systematically eliminated by regressing each factor considered (biomass of $T$. larynx, biomass of other species, temperature, irradiance, salinity and fluarescence) against depth using a polynomial function of order (linear, quadratic, cubic, etc.) determined by the best fit of the data. This procedure allowed us to determine the relative effects of factors other than depth on residual variation. The depth regression analyses were made on the square roots of standardized data (Hair et al. 1992). Multiple regressions were carried out on the residuals of these 6 regressions. To determine the factors or the combination of factors which best explained the variation of the residuals, the sequential multiple stepwise regressions was used (Draper \& Smith 1981).

Field experiments: Experimental results were expressed as dry mass $(\mathrm{g})$ of Tubularia larynx colonies. For extract and metabolite experiments, a randomized complete block design (Milliken \& Johnson 1992), with collectors as a random term (SAS Institute 1991), was carried out on Box-Cox transformed data (with progiciel R; Legendre \& Vaudor 1991). The influence of substrate heterogeneity was tested on log transformed data in order to meet assumptions of normality and homoscedasticity of residuals. A Latin square ANOVA (Sokal \& Rohlf 1981), with collectors as a random term, was used on the transformed data. This type of experimental design was used to control for unknown but potential effects of position of microscopic slides on the collectors due to factors such as directional flow. A 1 way ANOVA (Sokal \& Rohlf 1981) was used on log transformed data to test significance due to extracts of various species.

Laboratory experiments: Experiments without choice: Experimental results were expressed as percentage of settled actinulae. Angular transformations (Sokal \& Rohlf 1981) on data sets were used to meet assumptions of normality and homoscedasticity of residuals. These were confirmed by Shapiro \& Wilk's and Levene tests respectively (SAS Institute 1991). We analysed the effects of temperature, light, extracts and metabolites using a randomized complete block design (Milliken \& Johnson 1992). The statistical model used for this type of analysis had the following form:

$$
Y_{i j k}=u+T_{1}+F_{i}+T F_{i j}+e_{k(j)}
$$

where $Y_{i j k}$ is the settlement percentage on the $k$ th Petri dish in the $j$ th trial and within the $i$ th treatment factor (temperature, light, etc.); $u$ is the overall mean of the settlement percentage $e_{i} T_{\text {, is the random effect of trial }}$ $F_{j}$ is the fixed effect of treatment factors; $T F_{i j}$ is the 
interaction between trial and treatment factor; $e_{k(i j)}$ is the random error component. Furthermore, we identified by $S_{T}^{2}, S_{T F}^{2}$ and $S_{\text {e }}^{2}$ the variances of the random effects $T_{i}, T F_{i j}$ and $e_{k(i j)}$ respectively. The effect of substrate heterogeneity was analysed using a 1-way ANOVA (Sokal \& Rohlf 1981). When significant differences were found, the ANOVA was followed by LSMeans using Bonferroni's correction.

Experiments with choice: For these experiments, 2 ANOVAs were carried out in order to test: (1) whether actinulae had a preferred concentration of extracts and metabolites and if there was a preferred substrate heterogeneity at settlement; and (2) whether actinulae preferred extract, metabolite, and heterogeneity treated surfaces or untreated surfaces at settlement. For the first analysis a randomized complete block design (see Eq. 1) was made on angular transformed percentages of total settlement. For the second analysis, an index of settlement selectivity (S) between treatments and controls for each Petri dish was used. The use of an index was necessary because of the high proportion of non-settlement recorded in different sections of each dish, making the data to be irremediably heteroscedastic. This index (S) was calculated as follows:

$$
\mathrm{S}=\left(\mathrm{S}_{\mathrm{T}}-\mathrm{S}_{\mathrm{C}}\right) /\left(\mathrm{S}_{\mathrm{T}}+\mathrm{S}_{\mathrm{C}}\right)
$$

where $S_{T}$ was the percentage of settled actinula on the treated surface and $S_{C}$ was the percentage of actinula on the control surface of each Petri dish. The index varied between -1 , all actinula settled on the control side and +1 , all settled on the treated side. A randomized complete block design (Eq. 1) was carried out on values from this index.

The normality and homoscedasticity assumptions of residuals for the randomized complete block design were confirmed by Shapiro \& Wilk's and Levene tests respectively (SAS Institute 1991). LSMeans using Bonferroni's correction were made when ANOVA showed a significant difference.

\section{RESULTS}

\section{Field observation studies}

\section{Environmental conditions}

The environmental conditions likely to influence hydroid settlement at the study site in 1992 and 1993 are presented in Table 2 . These were comparable to those recorded at the same field site in 1985, 1987 (Bonardelli et al. 1993) and 1989 (Cóté et al. 1993). Temperature $\left(<16^{\circ} \mathrm{C}\right)$ and irradiance $\left(<632 \mu \mathrm{Ein} \mathrm{m}^{-2}\right.$ $\mathrm{s}^{-1}$ ) decreased rapidly with depth. The latter showed by far the largest decline, since a larger than $100 \times$ difference was observed between the 22 and $2 \mathrm{~m}$ depths (in 1993). Fluorescence also decreased with depth by a 1 -fold difference, but variation was large. In general, mean current velocity was high $\left(>9.76 \mathrm{~cm} \mathrm{~s}^{-1}\right)$. Large values were located close to the surface or near the bottom while slightly reduced values were observed in mid-water. Wet mass of other species, taken here as an index of potential interaction level with Tubularia larynx, was relatively high, but variation with depth was substantial and showed no coherent pattern (Table 2).

\section{Depth of maximum recruitment}

ANOVA carried out on the 1992 results of actinula recruitment indicate no difference between buoys but a significant depth effect on recruitment. Multiple pairwise comparisons showed that recruitment of Tubularia larynx was maximum ( $1.297 \mathrm{~g} \pm 0.365$; mean \pm SE) at $12 \mathrm{~m}$ depth (Fig. 3). Lowest recruitment
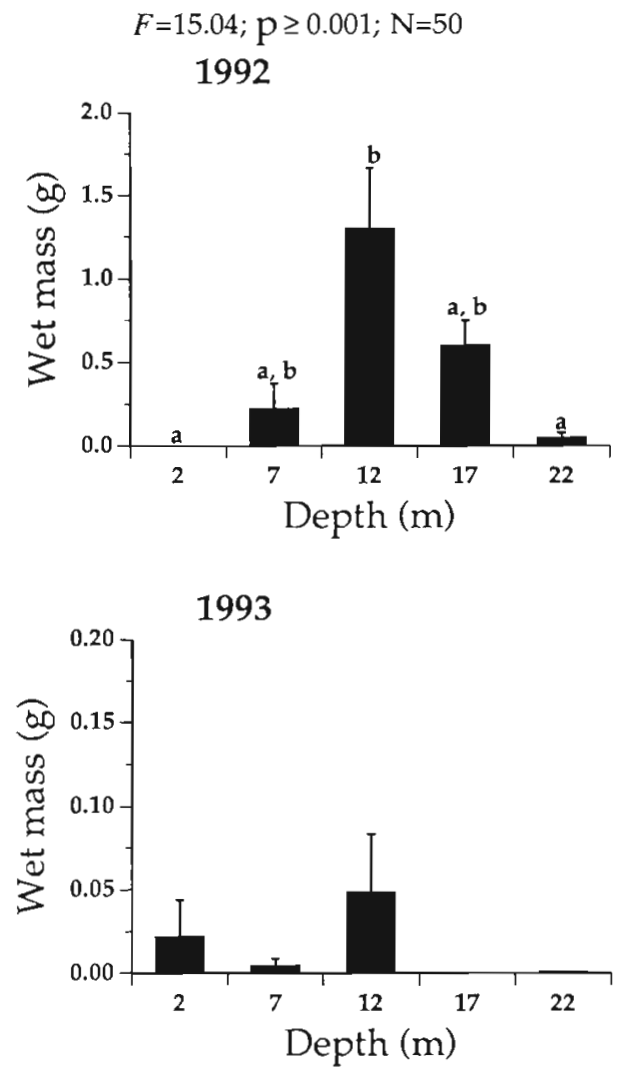

Fig. 3. Tubularia larynx. Field recruitment [wet mass $(g) \pm S E]$ of colonies as a function of depth for 1992 and 1993. Bars having dissimilar letters above them differed significantly from each other by LSMeans tests. Note different scales for the $y$-axes 
Table 3. Tubularia larynx. Stepwise multiple regressions among standardızed residuals of wet mass, standardized residuals of wet mass of other species and standardized residuals of physical factors without the depth contribution (see 'Methods'). The variables are presented in the order they were entered in the model. Model $R^{2}=0.45 ; N=50 . \cdot 0.05 \geq p>0.01, \cdots p \leq 0.001$

\begin{tabular}{|c|c|c|c|c|c|c|}
\hline Variable & $\begin{array}{l}\text { Order } \\
\text { entered }\end{array}$ & $\begin{array}{l}\text { Regression } \\
\text { coefficient }\end{array}$ & $\begin{array}{l}\text { Standard } \\
\quad \text { error }\end{array}$ & $\begin{array}{l}t \text {-Statistic } \\
\left(\mathrm{H}_{0}: b_{1}=0\right)\end{array}$ & $\begin{array}{l}\text { Standardized } \\
\text { regression coefficlents }\end{array}$ & $\begin{array}{c}\text { Partial } \\
\mathrm{R}^{2}\end{array}$ \\
\hline Temperature & 1 & 1.6665 & 0.30661 & $5.435^{\cdots}$ & 0.95524 & 0.3800 \\
\hline Irradiance & 2 & 0.0752 & 0.03074 & $-2.446^{\bullet}$ & 0.42993 & 0.0700 \\
\hline Intercept & & 0.0000 & 0.02746 & -0.0001 & & \\
\hline
\end{tabular}

occurred in the surface $2 \mathrm{~m}(0.003 \mathrm{~g} \pm 0.002)$ and near the bottom at $22 \mathrm{~m}(0.050 \mathrm{~g} \pm 0.029)$ of the water column. Actinulae did not recruit on a high proportion (82\%) of slides in 1993, and no statistical analysis was carried out. However, as in 1992, maximum hydroid recruitment was at $12 \mathrm{~m}$ (Fig. 3).

Relationship between recruitment of Tubularia larynx and environmental factors

The stepwise regression (see 'Methods') indicate that the best resolution from Model $\mathrm{R}^{2}$ was obtained by a combination of water temperature and irradiance (Table 3). The following equation was produced:

$$
y=1.6665 X_{1}+0.0752 X_{2}
$$

where $y$ is the residual betwcen biomass of Tubularia larynx and depth, $X_{1}$ is the residual between temperature and depth and $X_{2}$ the residual between solar irradiance and depth (see 'Methods'). Both variables were positively correlated with wet mass of hydroid colonies. These 2 factors combined explained $45 \%$ of the variation in wet mass of $T$. larynx colonies.

\section{Field experiments}

Influence of extracts, metabolites and substratum heterogeneity

There were no significant effects $(p>0.05)$ of hydroid extracts or metabolites on recruitment of Tubu-

Table 4. Tubularia larynx. ANOVA showing the effect of trials, treatment and interactions on the percentage of settled actinulae for each experiment without choice. Data were transformed to meet the normality and homoscedasticity assumptions of residuals using angular transformations of settled actinulae. The expected mean squares (EMS) were calculated according to the models shown in the right-hand column. See 'Methods - Statistical analysis' for definitions of variables. Q: quadratic forms.

The model was the same for the metabolite (Expt E) and extract (Expt F) experiments. $\cdots 0.01 \geq p>0.001, \cdots p \leq 0.001$

\begin{tabular}{|c|c|c|c|c|c|}
\hline Expt & Sources of variation & $\mathrm{df}$ & MS & $F$ & EMS \\
\hline \multirow[t]{4}{*}{ (A) Temperature } & Trials & 3 & 0.104 & 2.25 & \multirow{4}{*}{$\begin{array}{l}S_{e}^{2}+4 S_{T F}^{2}+12 S^{2} T \\
S_{e}^{2}+4 S_{T F}^{2}+Q S_{T}^{2} \\
S_{e}^{2}+4 S_{T F}^{2}\end{array}$} \\
\hline & Among temperatures & 2 & 0.717 & $15.49^{\cdots}$ & \\
\hline & Trials $\times$ Temperatures & 6 & 0.046 & 1.67 & \\
\hline & Error & 36 & 0.027 & & \\
\hline \multirow[t]{4}{*}{ (B) Light intensity } & Trials & 3 & 0.048 & 0.99 & \multirow{6}{*}{$\begin{array}{l}S_{e}^{2}+3 S_{T F}^{2}+18 S^{2} \\
S_{e}^{2}+3 S_{T F}^{2}+Q S^{2} T \\
S_{e}^{2}+3 S_{T F}^{2}\end{array}$} \\
\hline & Among light intensities & 5 & 0.107 & 2.20 & \\
\hline & Trials $\times$ Light intensities & 15 & 0.046 & 1.33 & \\
\hline & Error & 48 & 0.036 & & \\
\hline \multirow[t]{2}{*}{ (C) Heterogeneity } & Among heterogeneities & 4 & 0.424 & \multirow[t]{2}{*}{$17.48 \cdots$} & \\
\hline & Error & 20 & 0.024 & & \\
\hline \multirow[t]{4}{*}{ (E) Metabolites } & Trials & 2 & 1.291 & $45.02 \cdots$ & \multirow{8}{*}{$\begin{array}{l}S^{2}+5.882 S_{T F}^{2}+29.412 S_{T}^{2} \\
S_{e}^{2}+6.875 S_{T F}^{2}+Q S_{T}^{2} \\
S_{e}^{2}+6.875 S_{T F}^{2}\end{array}$} \\
\hline & Among concentrations & 4 & 0.036 & 1.23 & \\
\hline & Trials $\times$ Concentrations & 8 & 0.029 & 1.1 .4 & \\
\hline & Error & 105 & 0.0255 & & \\
\hline \multirow[t]{4}{*}{ (F) Extract } & Trials & 2 & 2.806 & $23.15^{\cdots}$ & \\
\hline & Among concentrations & 4 & 0.347 & 2.56 & \\
\hline & Trals $\times$ Concentrations & 8 & 0.135 & $3.56^{*}$ & \\
\hline & Error & 105 & 0.037 & & \\
\hline
\end{tabular}


laria larynx in experiments carried out in the field. A similar result was obtained with the substrate heterogeneity tests. Results of 1 -way ANOVA showed no significant effect $(p>0.05)$ of the 8 extracts of different species and control solution on recruitment of $T$. larynx. On average, however, recruitment of 3 out of 4 treatments with extracts of algae (Laminaria digitata, Palmaria palmata and diatoms) was higher than those observed for extracts of animals.

\section{Laboratory experiments}

Expt A: Temperature

Temperature significantly influenced ( $p \leq 0.001$ ) the settlement of actinulae (Table 4). Settlement at 5 and $10^{\circ} \mathrm{C}$ was significantly lower than at $15^{\circ} \mathrm{C}$ (Fig. 4). A high proportion of settled actinulae, between $100 \pm$ $0 \%( \pm \mathrm{SE})$ for trial 1 and $11 \pm 11 \%$ for trial 4 , appeared damaged, as defined by Fig. $2 \mathrm{C}$ in the $15^{\circ} \mathrm{C}$ treatment. At $10^{\circ} \mathrm{C}$, damaged actinulae $(25 \pm 25 \%)$ were observed in trial 2 only. No damaged actinulae were observed at $5^{\circ} \mathrm{C}$

\section{Expt B: Light intensity}

The result of the ANOVA (Table 4) showed that light intensity did not influence significantly actinula settlement in the laboratory

\section{Expt C: Substratum heterogeneity. Experiment without choice}

The results of this experiment (Table 4) showed that smooth surfaces $(0 \mu \mathrm{m}$, epoxy alone and control, no epoxy and no sand) were preferred to rough surfaces. Among the rough surfaces, there was a lower settlement intensity with smaller particle grain size (Fig. 4)

\section{Expt D: Substratum heterogeneity. Experiment with choice}

For all trials, whether with 25 or 50 actinula per dish, there was a significant effect of substrate heterogeneity on total settlement of actinulae (Table 5). Settlement was higher in dishes with heterogeneity levels of 0 than in those with heterogeneity levels of 250,500 or $1000 \mu \mathrm{m}$ (Fig. 5). Settlement, in experiments with 50 actinulae per dish, varied significantly among trials (Table 5)

\section{Experiment A}

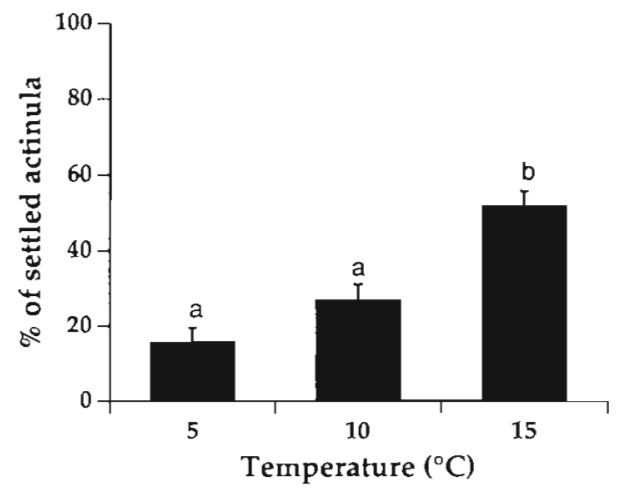

Experiment $\mathrm{C}$

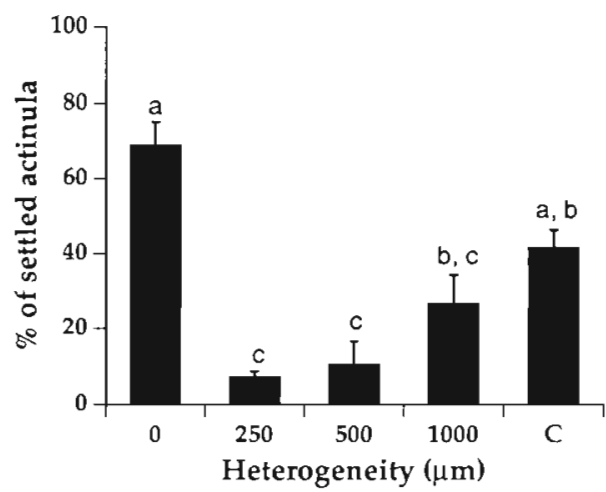

Fig. 4. Tubularia larynx. Percent $( \pm S E)$ of settled actinulae for experiments as a function of temperature (Expt $A$ ) and substrate heterogeneity (Expt C). Bars having dissimilar letters above them differ significantly from each other by LSMeans tests using Bonferroni's correction. Control (C), Petri dish without epoxy and sand; $0 \mu \mathrm{m}$, Petri dish with epoxy and without sand

When the treatment effects were measured using the selectivity index, S (Eq. 2), few significant effects were observed. A significant effect $(0.05 \geq p>0.01)$ in crossed factors (trials $\times$ heterogeneity) was observed in trials with 50 actinulae per dish (Table 6). As shown in Fig. 6, among heterogeneous surfaces, variations among trials increased with heterogeneity. No other common trend in the pattern of settlement was observed among trials.

\section{Expt E: Tubularia larynx metabolites. Experiment without choice}

Settlement did not differ with concentration of Tubularia larynx metabolites (Table 4). Furthermore, settlement of actinulae differed significantly $(p \leq 0.001)$ among trials (Table 4). 
Table 5. Tubularia larynx. ANOVA showing the effect of trials, treatment and crossed factors on the total proportion of actinulae settled for each experiment with choice. Data were transformed to meet the normality and homoscedasticity assumptions of residuals using angular transformations of settled actinulae. The expected mean squares (EMS) were calculated according to the models shown in the right-hand column. See 'Methods-Statistical analysis' for definitions of variables. $Q$ : quadratic forms The models were the same for all experiments. $\cdot 0.05 \geq p>0.01, \cdots 0.01 \geq p>0.001, \cdots p \leq 0.001$

\begin{tabular}{|c|c|c|c|c|c|}
\hline Expt & Sources of variation & $\mathrm{df}$ & MS & $F$ & EMS \\
\hline $\begin{array}{l}\text { (D) Heterogeneity } \\
25 \text { actinulae per dish }\end{array}$ & $\begin{array}{l}\text { Trials } \\
\text { Among heterogeneities } \\
\text { Trials } \times \text { Heterogeneity } \\
\text { Error }\end{array}$ & $\begin{array}{r}2 \\
3 \\
6 \\
48\end{array}$ & $\begin{array}{l}0.094 \\
0.304 \\
0.057 \\
0.026\end{array}$ & $\begin{array}{l}1.628 \\
5.26^{\circ} \\
2.21\end{array}$ & $\begin{array}{l}S_{e}^{2}+5 S_{T F}^{2}+20 S_{T}^{2} \\
S_{e}^{2}+5 S_{T F}^{2}+Q S_{T}^{2} \\
S_{e}^{2}+5 S_{T F}^{2}\end{array}$ \\
\hline $\begin{array}{l}\text { (D) Heterogeneity } \\
50 \text { actinulae per dish }\end{array}$ & $\begin{array}{l}\text { Trials } \\
\text { Among heterogeneities } \\
\text { Trlals } \times \text { Heterogeneity } \\
\text { Error }\end{array}$ & $\begin{array}{r}2 \\
3 \\
6 \\
48\end{array}$ & $\begin{array}{l}0.278 \\
0.563 \\
0.034 \\
0.035\end{array}$ & $\begin{array}{c}8.00^{\circ} \\
16.16^{*} \\
0.98\end{array}$ & \\
\hline $\begin{array}{l}\text { (G) Metabolites } \\
25 \text { actinulae per dish }\end{array}$ & $\begin{array}{l}\text { Trials } \\
\text { Among concentrations } \\
\text { Trials } \times \text { Concentration } \\
\text { Error }\end{array}$ & $\begin{array}{r}2 \\
3 \\
6 \\
48\end{array}$ & $\begin{array}{l}0.228 \\
0.012 \\
0.064 \\
0.012\end{array}$ & $\begin{array}{l}3.53 \\
0.19 \\
5.04 \cdots\end{array}$ & \\
\hline $\begin{array}{l}\text { (G) Metabolites } \\
50 \text { actinulae per dish }\end{array}$ & $\begin{array}{l}\text { Trials } \\
\text { Among concentrations } \\
\text { Trials } \times \text { Concentration } \\
\text { Error }\end{array}$ & $\begin{array}{r}2 \\
3 \\
6 \\
48\end{array}$ & $\begin{array}{l}1.762 \\
0.040 \\
0.084 \\
0.013\end{array}$ & $\begin{array}{l}20.83^{\cdots} \\
0.47 \\
6.21 \cdots\end{array}$ & \\
\hline $\begin{array}{l}(\mathrm{H}) \text { Extract } \\
25 \text { actinulae per dish }\end{array}$ & $\begin{array}{l}\text { Trials } \\
\text { Among concentrations } \\
\text { Trials } \times \text { Concentration } \\
\text { Error }\end{array}$ & $\begin{array}{r}2 \\
3 \\
6 \\
48\end{array}$ & $\begin{array}{l}0.021 \\
0.115 \\
0.063 \\
0.034\end{array}$ & $\begin{array}{l}0.33 \\
1.81 \\
1.84\end{array}$ & \\
\hline $\begin{array}{l}\text { (H) Extract } \\
50 \text { actinulae per dish }\end{array}$ & $\begin{array}{l}\text { Trials } \\
\text { Among concentrations } \\
\text { Trials } \times \text { Concentration } \\
\text { Error }\end{array}$ & $\begin{array}{r}2 \\
3 \\
6 \\
48\end{array}$ & $\begin{array}{l}0.200 \\
0.142 \\
0.025 \\
0.039\end{array}$ & $\begin{array}{l}7.81^{\circ} \\
5.54^{\circ} \\
0.64\end{array}$ & \\
\hline
\end{tabular}

Expt F: Tubularia larynx extracts.

Experiment without choice

There was a significant influence $(0.01 \geq p>0.001)$ of the crossed factors (trials $\times$ extract concentrations) on settlement of actinula (Table 4). In general, there was an overall increase in settlement with increasing extract concentration, but the differences among treatments within trials were not always significant (Fig. 7) due to large unexplained variation among treatments within trials
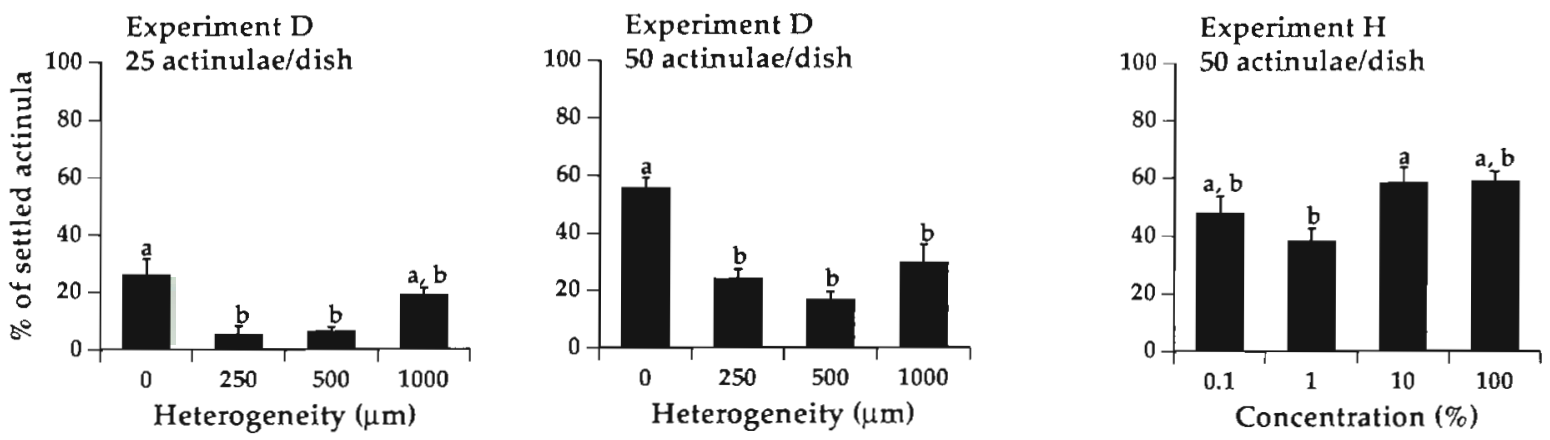

Fig. 5. Tubularia larynx. Percent ( \pm SE) of total settled actinulae (treated + control sides) in each dish as a function of substrate heterogeneity (Expt D) and concentration of adult extracts (fractions of initial solution; see 'Methods') (Expt H) for experiments with choice for combined trials ( $N=20$ per Petri dish per trial). Bars having dissimilar letters above them differ significantly from each other by LSMeans tests using Bonferroni's correction. 
Table 6. Tubularia larynx. ANOVA showing the effect of trials, treatment and crossed factors on the selectivity index (S; see 'Methods') of actinulae for each experiment with choice. The expected mean squares (EMS) were calculated according to the models shown in the right-hand column. See 'Methods - Statistical analysis' for definitions of variables. Q: quadratic forms. The models were the same for all experiments. $\cdot 0.05 \geq p>0.01, \cdot 0.01 \geq p>0.001$

\begin{tabular}{|c|c|c|c|c|c|}
\hline Expt & Sources of variation & $\mathrm{df}$ & MS & $F$ & EMS \\
\hline (D) Heterogeneity & Trials & 2 & 0.414 & 0.792 & $S_{e}^{2}+5 S_{T F}^{2}+20 S_{T}^{2}$ \\
\hline \multirow{3}{*}{25 actinulae per dish } & Among heterogeneities & 3 & 1.361 & 2.60 & $S^{2}+5 S_{T F}^{2}+Q S_{T}^{2}$ \\
\hline & Trials $\times$ Heterogeneity & 6 & 0.523 & 1.28 & $S_{\mathrm{c}}^{2}+5 S_{T F}^{2}$ \\
\hline & Error & 48 & 0.406 & & \\
\hline (D) Heterogeneity & Trials & 2 & 0.194 & 0.33 & \\
\hline \multirow[t]{3}{*}{50 actinulae per dish } & Among heterogeneities & 3 & 0.647 & 1.11 & \\
\hline & Tnals $\times$ Heterogeneity & 6 & 0.579 & $2.74^{\circ}$ & \\
\hline & Error & 48 & 0.210 & & \\
\hline (G) Metabolites & Trials & 2 & 0.200 & 0.13 & \\
\hline \multirow{3}{*}{25 actinulae per dish } & Among concentrations & 3 & 0.283 & 0.19 & \\
\hline & Trials $\times$ Concentration & 6 & 1.483 & $3.36^{\cdots}$ & \\
\hline & Error & 48 & 0.440 & & \\
\hline (G) Metabolites & Trials & 2 & 0.023 & 0.03 & \\
\hline \multirow[t]{3}{*}{50 actinulae per dish } & Among concentrations & 3 & 0.577 & 0.88 & \\
\hline & Trials $\times$ Concentration & 6 & 0.649 & 1.05 & \\
\hline & Error & 48 & 0.615 & & \\
\hline (H) Extract & Trials & 2 & 0.629 & 1.21 & \\
\hline \multirow{3}{*}{25 actinulae per dish } & Among concentrations & 3 & 0.739 & 1.42 & \\
\hline & Trials $\times$ Concentration & 6 & 0.518 & 0.85 & \\
\hline & Error & 48 & 0.608 & & \\
\hline (H) Extract & Trials & 2 & 0.718 & 0.74 & \\
\hline \multirow{3}{*}{50 actinulae per dish } & Among concentrations & 3 & 0.521 & 0.54 & \\
\hline & Trials $\times$ Concentration & 6 & 0.962 & 1.56 & \\
\hline & Error & 48 & 0.614 & & \\
\hline
\end{tabular}

Expt G: Tubularia larynx metabolites. Experiment with choice

For the series of experiments with 50 actinulae per dish, there were significant differences $(0.01 \geq p \geq$
0.001 ) in settlement among trials (Table 5). Both sets of experiments (with 25 and 50 actinulae per dish) showed significant interactions (trials $\times$ concentrations), indicating variable settlement responses to concentration among trials, suggesting that the effect of
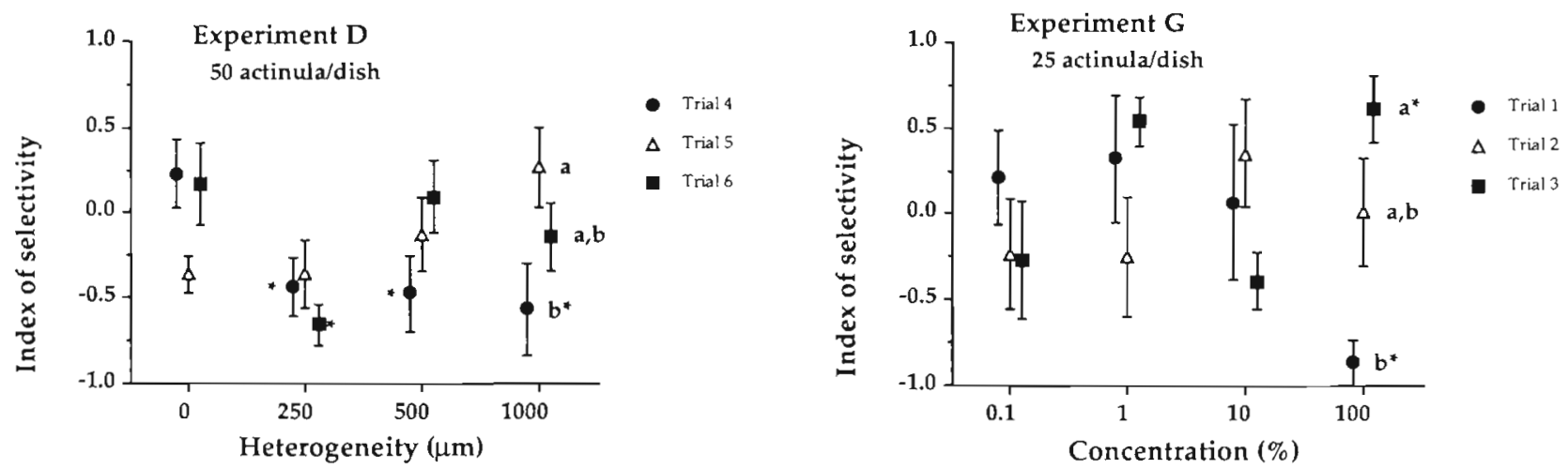

Fig. 6. Tubularia larynx. Index ( $\pm \mathrm{SE}$ ) of microhabitat selectivity ( $\mathrm{S}$; see 'Methods') of actinula between treated and control sides of dishes as a function of substrate heterogeneity (Expt D) and concentration of adult metabolites (fraction of initial solution; see 'Methods') (Expt G) for experiments with choice and for each trial ( $\mathrm{N}=20$ per Petri dish per trial). Data points having dissimilar letters above them differ significantly from each other by LSMeans tests using Bonferroni's correction. Data points with asterisks differ significantly from 0 at $0.05 \geq p>0.01$. Positive $S$ value indicates strong selection for the condition tested for 

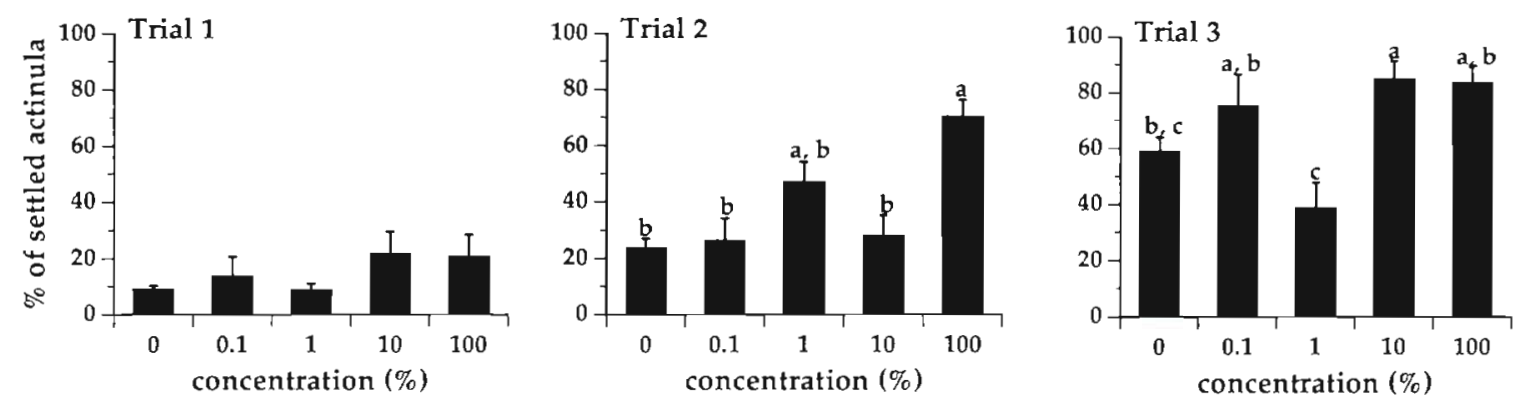

Fig. 7 Tubularia larynx. Percent $\{ \pm S E$ ) of settled actinulae at 5 concentrations of adult extracts (fractions of initial solution; see 'Methods') for experiments without choice. Bars having dissimilar letters above them differ significantly from each other by LSMeans tests using Bonferroni's correction

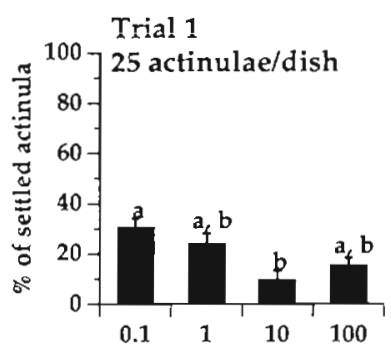

Trial 3

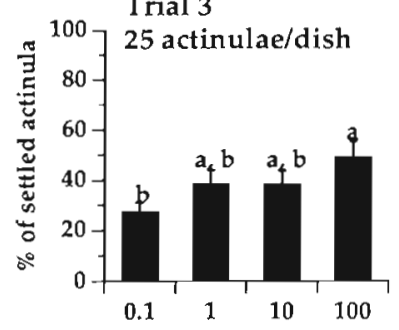

Trial 5

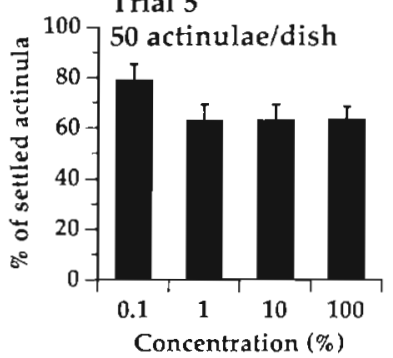

Trial 2

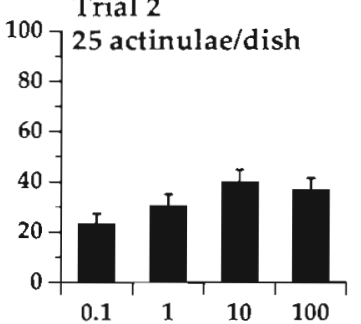

Trial 4

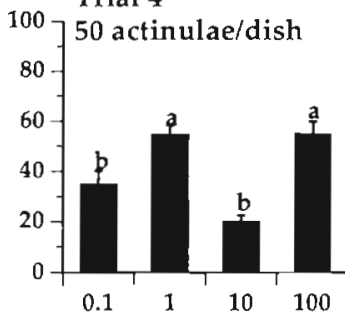

Trial 6

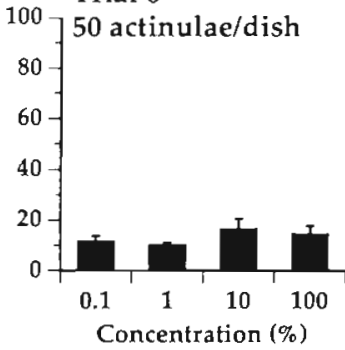

Fig. 8. Tubulana larynx. Percent $( \pm$ SE) of total settled actınulae (treated + control sides) in each dish as a function of concentration of adult metabolites (fraction of inıtial solution; see 'Methods') for experiments with choice. Bars having dissimilar letters above them differ significantly from each other by LSMeans tests usıng Bonferroni's correction

metabolite concentration on settlement was not strong (Fig. 8)

The weak influence of metabolite concentration on settlement was also evident when the analysis was carried out using tho sclectivity index (S), and no significant influence of metabolite concentration on settlement became detectable in the experiments even though a significant interaction $(0.05 \geq p>0.01)$ between trials and concentrations was observed in trials using 25 actinulae (Table 6). This interaction was due to differing settlement preference among trials between the treated and untreated sides of dishes with metabolite concentrations of $100 \%$ (Fig. 6).

\section{Expt H: Adult Tubularia larynx extract. Experiment with choice}

Results of the effect of Tubularia larynx extract concentrations on settlement were mixed. For trials with 25 actinulae per Petri dish, the ANOVA revealed no significant effect ( $p>0.05$ ) of extract concentrations on total settlement (Table 5). For trials with 50 actinulae, the ANOVA revealed a significant effect $(0.05 \geq \mathrm{p} \geq$ $0.01)$ of extract concentrations on total settlement (Table 5). There was also a significant effect $(0.05 \geq \mathrm{p} \geq$ 0.01 ) of trials in this experiment. As in the experiment without choice (Expt F), there was an overall increase in settlement with higher extract concentration (Fig. 5). There was no significant effect $(p>0.05)$ of treatment on selectivity indices for the 2 series of experimental trials (Table 6).

\section{DISCUSSION}

\section{Settlement biology}

Sexual reproduction of hydroids of the genus Tubularia results in the liberation of actinulae from the 
gonophore of the female (Allman 1872). These are not larvae in the proper sense, but small juvenile polyps (Allman 1872, Berrill 1952, Hawes 1958). Hence, actinulae settlement is not accompanied by major morphological or physiological changes characteristic of metamorphoses in many marine larvae (Pyefinch \& Downing 1949, Hawes 1958). Indeed, the short interval between liberation of actinulae by the female gonophore and settlement is believed to be equivalent to the time necessary to transform cnidoblasts into nematocysts (Hawes 1958). Under laboratory conditions the delay for this transformation is 2 to $4 \mathrm{~d}$, and is shorter as water temperature rises (Pyefinch \& Downing 1949). The nematocysts, which pack the tips of the aboral tentacles (see Fig 2B), are responsible for the initial attachment of the actinula to a substrate. After initial settlement, elongation of the aboral region of the actinula (see Fig. 2B) takes place and permanent attachment occurs when this region is long enough to come into contact with the substrate (Pyefinch \& Downing 1949, Sommer 1990). Permanent attachment is due to secretions of the ectoderm at the tip of the aboral pole (Lowe 1926, Pyefinch \& Downing 1949) It seems that this region of the ectoderm secretes the attachment cement when the aboral pole of the actinula body comes into contact with a substrate.

\section{Effect of physical factors on recruitment of Tubularia larynx}

The field results show that Tubularia larynx is not evenly distributed with depth (Fig. 3). Multiple regression on recruitment residuals (1992 data, Table 3) shows that 2 physical factors alone, temperature and solar irradiance, explain $45 \%$ of the variance observed in recruitment of $T$ larynx. It is possible that the small variation in temperature and solar irradiance encountered in a relatively shallow depth is responsible for the relatively small percentage of explanation of the variance due to these factors. These 2 factors are discussed in detail along with the results of the laboratory experiments. However, since $55 \%$ of the variation remained unexplained, other factors also influence recruitment of $T$. larynx.

According to Boero \& Fresi (1986), vertical hydroid zonation is caused by complex gradients of numerous factors which extend from the surface to deeper water. Hydrodynamic forces are probably the most important factor (cf. Ambrogi et al. 1988). Pyefinch \& Downing (1949) suggested that settlement occurs only when current velocity is low (0 to $1 \mathrm{~cm} \mathrm{~s}^{-1}$ ) and settling actinula (using tentacles for initial attachment) are dislodged when current velocity reaches $8 \mathrm{~cm} \mathrm{~s}^{-1}$ In our study minimum average current speed was observed in 1993 at a depth of $12 \mathrm{~m}$, where the maximum hydroid mass was observed (Table 2), confirming that this factor may play a role in Tubularia larynx recruitment. It should be noted, however, that during the tidal phase, current speed will oscillate from near 0 to high values, thus allowing sufficient low current time for the actinula to attach more permanently. Light could influence settlement directly (Williams 1965, Teitelbaum 1966) or indirectly by favouring diatom growth on substrates in the surface waters (Stevenson \& Stoermer 1981, Hudon \& Bourget 1983), thus pre-empting space. The high mass of other species, especially mollusks (Table 2), on collectors at 2 and $7 \mathrm{~m}$ could also suggest strong interspecific space competition (Claereboudt et al. 1994), given the fact that in our experiments these were primary space users not colonized by $T$. larynx.

\section{Effect of physical factors on settlement of Tubularia larynx}

Temperature

In laboratory experiments, temperature appears to influence both the rate of settlement as well as the success of the attachment process. The highest temperature tested $\left(15^{\circ} \mathrm{C}\right)$ was more favourable for settlement than other temperatures (Fig 4A). Hawes (1958) hypothesized that the settlement process is shortened at high temperatures. The high settlement observed at high temperatures in our experiments is in agreement with that hypothesis. Hence, settlement could have occurred more rapidly at $15^{\circ} \mathrm{C}$ compared to lower temperatures and may have been responsible for the high proportion of damaged actinulae observed at $15^{\circ} \mathrm{C}$ (see Fig. 2C). Actinulae do not have significant vitella or energy reserves (Crisp 1984) and they must begin feeding shortly after attachment. In an environment without food (e.g. Petri dishes), energy reserves of the actinulae may be expended more quickly at high temperatures with death and decomposition occurring faster than at low temperatures.

In our laboratory experiments, successful settlement rarely reached more than $70 \%$. Pyefinch \& Downing (1949) observed that the proportion of settled actinulae was rarely less than $90 \%$, while in Hawes (1958), only in one case was the proportion less than $100 \%$. The experiments reported in Hawes' (1958) often lasted up to $72 \mathrm{~h}$ with high temperatures (e.g. 21 to $26^{\circ} \mathrm{C}$ ). In experiments where conditions were more comparable to ours (in darkness and 14 to $19^{\circ} \mathrm{C}$ ), $102 \mathrm{~h}$ were necessary for settlement of all actinulae (Hawes 1958) Actinula maturity is another factor which could explain 
differences in settlement success compared with that observed in other studies. In Hawes' (1958) experiments, experimental actinulae were collected over a period extending up to $12 \mathrm{~h}$ and some experiments were carried out with actinulae from the second or third cohort of actinulae, i.e. actinulae collected 1 or $2 \mathrm{~d}$ after collection of mature colonies. These may have exhibited higher settlement rates (sensu Pyefinch \& Downing 1949) than the youngest cohort. In our experiments, the delay between colony collection and the experiment was always approximately $7 \mathrm{~h}$ (see 'Methods'), and only actinulae from the first cohort were used

An effect of temperature was also observed in the field with recruitment (Table 3 ). The multiple regression analysis showed that temperature alone explained $38 \%$ of the variance in recruitment. When other factors are entered first in the model, $>35 \%$ of the variance is still explained by temperature. This is consistent with results of other studies showing that temperature is an important factor influencing the occurrence of the Tubularia larynx colonies (Morre 1939, Berrill 1948, Boero 1984, Boero \& Fresi 1986, Calder 1990).

\section{Light intensity}

Some authors have suggested that hydroid settlement may be influenced by light (Williams 1965, Teitelbaum 1966). Recruitment of Tubularia crocea was greater in shaded regions than on bright or darkened regions (McDougall 1943). McDougall (1943) suggested that light also acted directly on $T$. crocea by inhibiting growth of young colonies. The damaging or inhibitory effect of ultraviolet light on the metabolism and growth of young colonies has also been suggested (Klugh 1929, McDougall 1943, Boero 1984).

Our field observations (Table 3) showed that light intensity plays a role in actinula settlement. However, since settlement of Tubularia larynx in the laboratory, occurred in the dark as well as in a brighter environment, light intensity does not appear to be a very important factor directly influencing the settlement of T. larynx.

\section{Substratum heterogeneity}

Substrate heterogeneity is another factor which influences Tubularia larynx settlement. Pyefinch \& Downing (1949) observed that actinulae can attach to many types of surfaces, smooth or rough. Recent field experiments using panels of different heterogeneity and complexity, showed that $T$. larynx settled more frequently on flat panels or on panels with $100 \mathrm{~mm}$ grooves than on panels with 10 or $1 \mathrm{~mm}$ grooves or combinations of these 2 types of surfaces (Bourget et al. 1994). In an analogous series of field experiments, using similar types of panels, Lemire \& Bourget (1996) observed that $T$. crocea preferentially selected the most complex panels and seemed to prefer the most exposed surfaces of simple or complex panels. Similar results were recorded by Mullineaux \& Garland (1993) for $T$. crocea, suggesting that settlement behaviour is similar in this species. In our laboratory experiments, where heterogeneity factors were isolated from hydrodynamic processes, highest settlement always occurred where heterogeneity was $0 \mathrm{\mu m}$ (Control I and II), i.e. absence of measurable heterogeneity (Figs. 4 \& 6). The second preferred choice of actinula was always at a heterogeneity level $1000 \mu \mathrm{m}$. This indicates that flat surfaces or those with large-scale heterogeneity offer suitable conditions for settlement. Surfaces $1000 \mu \mathrm{m}$ wide are approximately the width of the aboral disc of the settling actinula and enable contact of the whole aboral pole with the substrate.

In the field experiments, no difference in settlement intensity was observed among substrate heterogeneities. This is probably because a variety of other environmental factors also influenced the settlement process. In several species, selectivity is known to decrease with age, the oldest larvae are less selective and often settle in less attractive sites (Crisp 1974 , Pawlik 1992). In our laboratory experiments, the actinulae were young, and probably highly selective; hence in dishes with favourable substrates actinulae settled, but in dishes with the less ideal substrates actinulae may have delayed their settlement. In the field, different aged actinulae are present at any given time, and it is possible that predominantly older actinulae settled on contact with the substrate. Another hypothesis is that few actinulae attached permanently because of the high water flow regime (Butman et al. 1988, Mullineaux \& Butman 1991). Pyefinch \& Downing (1949) suggested that attachment of actinulae to the substrate, by means of the tips of the aboral tentacles, occurs during slack-water periods with low currents $\left(<2 \mathrm{~cm} \mathrm{~s}^{-1}\right)$. Under tidal conditions, the time to settle may be limited; hence actinulae may be less selective in choosing a settlement site.

\section{Effect of chemical factors on settlement of Tubularia larynx}

Aggregation in hydrozoa is a well-known phenomenon (Williams 1976, Boero 1984). Aggregation increases the probability of fertilization (Crisp 1984, Pawlik 1992, Rodríguez et al. 1993). Positive responses to conspecific substances have been observed in many 
species of hydrozoa. In the laboratory the majority of the larvae of 2 hydrozoans, Clava squamata and Kirchenpauria pinnata, settled close to the existing adults, in general within a perimeter of $3 \mathrm{~cm}$ (Williams 1976). Chemical substances included in the mucus layer secreted by primary polyps of colonies are involved in this relationship (Williams 1976). Larval settlement near adult conspecifics was also observed in Tubularia larynx (Pyefinch \& Downing 1949). The planula of Haliclystus salpinx (Scyphozoa) settles more often near newly settled individuals (Otto 1978). Thus, when the density of larvae is low, settlement is delayed, perhaps because of the lack of settling factor (Otto 1978).

\section{Extracts and metabolites of Tubularia larynx}

In our studies, adult extracts had some influence on actinula settlement (see Tables 4 \& 5), but this influence was very variable among extract concentrations and trials. In general, actinulae settled more on surfaces treated with high concentrations of adult extracts than on surfaces treated with low concentrations, or with a control solution (sea water), suggesting that actinulae were able to recognize adult extracts as indicators of the presence of conspecifics. In contrast, however, Tubularia larynx actinula settlement was not induced or was influenced little by adult metabolites (Table 4).

Many reasons could explain why no significant differences were detected by the ANOVA on the extract index $(S)$ in the adult extract experiments (see Table 6). The most plausible explanation is that adult extracts soon become diluted throughout the dishes, making cues ubiquitous in the Petri dish, resulting in uniform settlement. A similar phenomenon was observed when high densities of Haliclystus salpinx planula were used by Otto (1978).

In field experiments, extract and metabolite treatments had no significant influence on recruitment of Tubularia larynx. It is probable that other factors (e.g. rapid dilution of solution adsorbed onto the substrate) weakened any effect of the 2 treatments. In this respect, the use of non-polar solvents to maximize the chances of continued activity would be desirable, though the body of literature is substantial (see Gabbott \& Larman 1987) describing the use of aqueous extracts applied directly to the substrate, such as in this study. Further, under natural conditions, aggregates, like those observed for Tubularia species, may also arise as a result of passive deposition of larvae in areas with low shear stress and a thick surface boundary layer (Keen 1987, Havenhand \& Svane 1991, Mullineaux \& Butman 1991).

\section{Other extracts}

Our experiment shows that no influence on Tubularia larynx settlement was observed using other animal or algal extracts in the field. However, 3 algal extract solutions (Laminaria digitata, Palmaria palmata and diatoms) had a greater, though nonsignificant, influence than animal extracts.

In summary, actinula larvae exhibited some microhabitat selectivity. This selectivity was dependent on: (1) temperature, settlement took place more quickly at higher temperatures; (2) substrate heterogeneity, larger particles $(1000 \mu \mathrm{m})$ presumably offering greater area for attachment; (3) light intensity, which probably indirectly influenced the settlement process; (4) and possibly on current velocity, greater settlement occurring at low water velocities. Finally, actinula responded variably to extracts from conspecifics under laboratory conditions.

Acknowledgements. The authors acknowledge field assistance by J.-Y. Anctil, J. Côté, E. Pilote and F. Pouliot. Thanks also to $\mathrm{M}$. Mingelbier and $\mathrm{E}$. Tamigneaux for their help and for physical data from 1992. We also thank G. Daigle, L. Lapointe and $\mathrm{M}$. Claereboudt for discussions and C. Lovejoy for linguistic improvements. This work was supported by NSERC and FCAR grants to E.B. and by GIROQ /Groupe interuniversitaire de recherches océanographiques du Québec). Contribution to the program of GIROQ

\section{LITERATURE CITED}

Allman G (1872) A monograph of the gymnoblastic or tubularian hydroids. Royal Society, London

Ambrogi AO, Bianchi CN, Morri C, Sconfietti R (1988) Recherches sur la zonation verticale du macrobenthos sessile dans la lagune de Venise. Cah Biol Mar 29:297-311

Bahamondes-Rojas I (1988) Induction de la métamorphose des larves d'Eubranchus doriae (Trinchèse, 1879), mollusque nudibranche, par des substances provenant de l'espèce proie Kirchenpaueria pinnata, Hydrozoaire, Cnidaire. Vie Mar 9:1-6

Berrill NJ (1948) Temperature and size in the reorganization of Tubularia. J Exp Zool 107:455-464

Berrill NJ (1952) Growth and form in gymnoblastic hydroids. V. Growth cycle in Tubularia. J Morphol 90:583-601

Boero F (1984) The ecology of marine hydroids and effects of environmental factors: a review. Mar Ecol 5:93-118

Boero F, Fresi E (1986) Zonation and evolution of a rocky bottom hydroid community. Mar Ecol 7:123-150

Bonar DB, Coon SL, Walch M, Weiner RM, Fitt W (1990) Control of oyster settlement and metamorphosis by endogenous and exogenous chemical cues. Bull Mar Sci 46: $484-498$

Bonardelli JC, Himmelman JH, Drinkwater K (1993) Current variability and upwelling along the North Shore of Baie des Chaleurs. Atmosphere-Ocean 31:541-565

Boudreau B, Bourget E, Simard Y (1990) Benthic invertebrate larval response to substrate characteristics at settlement: shelter preferences of the American lobster Homarus americanus. Mar Biol 106:191-198

Boudreau B, Bourget E, Simard Y (1993a) Effect of age, injury, 
and predator odors on settlement and shelter selection by lobster Homarus americanus postlarvae. Mar Ecol Prog Ser 93:119-129

Boudreau B, Bourget E, Simard Y (1993b) Behavioural responses of competent lobster postlarvae to odor plumes. Mar Biol 117:63-69

Bourget $E$ (1988) Barnacle larval settlement: the perception of cues at different spatıal scales. In: Chelazzi $G$, Vannini $M$ (eds) Behavioral adaptation to intertidal life. Plenum Press, New York, p 153-172

Bourget E, DeGuise J, Daigle G (1994) Scales of substratum heterogeneity, structural complexity and the early establishment of a marine epibenthic community. J Exp Mar Biol Ecol 181:31-51

Butman CA (1987) Larval settlement of soft-sediment invertebrates: the spatial scales of pattern explained by active habitat selection and the emerging role of hydrodynamical processes. Oceanogr Mar Biol Annu Rev 25:1.13-165

Butman CA, Grassle JP (1992) Active habitat selection by Capitella sp. I larvae. 1. Two-choice experiments in stult water and flume flows. J Mar Res 50:669-715

Butman CA, Grassle JP, Webb CM (1988) Substrate choices made by marine larvae setlling in still water and in a flume flow. Nature 333:771-773

Calder DR (1990) Seasonal cycles of activity and inactivity in some hydroids from Virginia and South Carolina, USA. Can J Zool 68:442-450

Chabot R, Bourget E (1.988) Influence of substratum heterogeneity and settled barnacle density on the settlement of cypris larvae. Mar Biol 97:45-56

Claereboudt MR, Bureau D, Côté J, Himmelman JH (1994) Fouling development and its effect on the growth of juvenile giant scallops (Placopecten magellanicus) in suspended culture. Aquaculture 121:327-342

Connell JH (1985) The consequence of variation in initial settlement vs post-settlement mortality in rocky intertidal communities. J Exp Mar Biol Ecol 93:11-45

Côté J, Himmelman JH. Claereboudt MR, Bonardelli JC (1993) Influence of density and depth on the growth of juvenile sea scallops (Placopecten magellanicus) in suspended culture. Can J Fish Aquat Sci 50:1857-1869

Crisp DJ (1974) Factors influencing the settlement of marine invertebrate larvae. In: Grant PT, Mackie AM (eds) Chemoreception in marme organisms. Academic Press, London, p 177-265

Cnsp DJ (1984) Overview of research on marine invertebrate larvae, 1940-1980. In: Costlow JD, Tipper RC (eds) Marine biodeterioration: an interdisiplinary study: proceedings of the symposium on marine biodeterioration. Spon, London, p 103-126

Crisp DJ, Meadows PS (1962) The chemical basis of gregariousness in cirripedes. Proc R Soc Lond B 156:500-520

Crisp DJ, Meadows PS (1963) Adsorbed layers: the stimulus to settlement in barnacles. Proc R Soc Lond B 158:364-387

Davis AR, Wright AE (1989) Interspecific differences in fouling of two congeneric ascidians (Eudistoma olivaceum and E. capsulatum): is surface acıdity an effective defense? Mar Biol 102:491-497

Dean TA, Hurd LE (1980) Development in an estuarine fouling community: the influence of early colonists on later arrivals. Oecologia 46:295-301

Draper WR, Smith H (1981) Applied regression analysis, 2nd edn. Wiley, New York

Eckman JE (1987) The role of hydrodynamics in recruitment, growth, and survival of Argopecten irradians (L.) and Anomia simplex (D'Orbigny) within eelgrass meadows. J Exp Mar Biol Ecol 106:165-191
Gabbott PA, Larman VN (1987) The chemical basis of gregariousness in cirnpedes: a review (1953-1984). In: Southward AJ (ed) Barnacle biology. Crustacean issues 5. AA Balkema, Rotterdam, p 377-388

Grassle JP, Butman CA, Mills SW (1992) Actrve habitat selection by Capitella sp. I larvae. II. Multiple-choice experiments in still water and flume flows. J Mar Res 50:71.7-743

Hadfield MG (1984) Settlement requirements of mollusca larvae: new data on chemical and genetic roles. Aquaculture $39: 283-298$

Hair JFJ, Anderson RE, Tatham RL, Black WC (1992) Multivariate data analysis, 3rd edn. Macmillan Publishing Company, New York

Harvey $M$, Bourget $E$, Ingram RG (1995) Experimental evidence of passive accumulation of bivalve larvar on filamentous epibenthic structures. Limnol Oceanogr 40 : $94-104$

Harvey M, Bourget E, Miron G (1993) Settlement of Iceland scallop Chlamys islandica spat in response to hydroids and filamentous red algae: field observations and laboratory experiments. Mar Ecol Prog Ser 99:283-292

Havenhand JN, Svane I (1991) Roles of hydrodynamics and larval behaviour in determining spatial aggregation in the tunicate Ciona intestinalis. Mar Ecol Prog Ser 68:271-276

Hawes FB (1958) Preliminary observations on the settlement of the actinula larva of the Tubularia larynx (Ellis \& Solander). Annls Mag Nat Hist 13:147-155

Hudon $C_{\text {, Bourget }} E$ (1983) The effect of light on the vertical structure of epibenthic diatom communities. Bot Mar 26: $317-330$

Hughes RG (1977) Aspects of the biology and life-history of Nemertesia antennina (L.) (Hydrozoa: Plumularidae). J Mar Biol Ass UK 57:641-657

Hughes RG (1983) The life-history of Tubularia indivisa (Hydrozoa: Tubulariidae) with observation on the status of $T$ ceratogyne. J Mar Biol Ass UK 63:467-479

Hughes RG (1986) Differences in the growth, form and life history of Plumularia setacea (Ellis and Solander) (Hydrozoa: Plumulariidae) in two contrasting hábitats. Proc $\mathrm{R}$ Soc Lond B 288:113-125

Hughes RG (1987) The loss of hydranths of Laomedea flexuosa Alder and other hydroids, with reference to hydroid senescence. In: Bouillon $J$, Boero F, Cicogna F, Cornelius PFS (eds) Modern trends in the systematics, ecology, and evolution of hydroids and hydromedusae. Clarendon Press, Oxford, p 171-184

Hughes RG, Henderson DHJ (1989) Morphologlcal adaptations of Aglaophenia harpago (Hydrozoa: Plumularidae) to enhance feeding efficiency. J Mar Biol Ass UK 69:17-25

Johnson CR, Muir DG, Reysenbach AL (1991) Characteristic bacteria associated with surfaces of coralline algae: a hypothesis for bacterial induction of marine invertebrate larvae. Mar Ecol Prog Ser 74:281-294

Katô T, Kumanıreng AS, Ichinose I, Kitahara $Y$, Kakinuma $Y$, Nishıhira M, Kato M (1975) Active componements of Sargassum tortile affecting the settlement of swimming larvae of Coryne uchidai. Experientıa 31:433-434

Keen SL (1987) Recruitment of Aurelia aurita (Cnidaria Scyphozoa) larvae is position-dependent, and independent of conspecific density, within a settling surface. Mar Ecol Prog Ser 38:151-160

Klugh AB (1929) The effect of the ultra-violet component of sunlight on certain organisms. Can J Res 1:100-109

Knight-Jones EW (1953) Laboratory experiments on gregariousness during setting in Balanus balanoides and other barnacles. J Exp Biol 30:584-599

Legendre P, Vaudor A (1991) Le progiciel R, Analyse multidi- 
mensionnelle, analyse spatial. Département de Science Biologiques, Université de Montréal, Montréal

Lemire $M$, Bourget E (1996) Substratum heterogeneity and complexity influence micro-habitat selection of Balanus sp. and Tubularia crocea larvae. Mar Ecol Prog Ser 135: $77-87$

Llobet I, Gili JM, Hughes RG (1991) Horizontal, vertical and seasonal distributions of epiphytic hydrozoa on the alga Halimeda tuna in the Northwestern Mediterranean Sea. Mar Biol 110:151-159

Lowe E (1926) The embryology of Tubularia larynx (Allman) Q J Microsc Sci 50:599-627

McDougall KD (1943) Sessile marine invertebrates of Beaufort, North Carolina. Ecol Monogr 13:321-374

Milliken GA, Johnson DE (1992) Analysis of messy data, Vol 1. Designed experiments. Chapman \& Hall, New York

Morre J (1939) The role or temperature in hydranth formation in Tubularia. Biol Bull Mar Biol Lab Woods Hole 76:104-107

Mullineaux LS, Butman C A (1991) lnitial contact, exploration and attachment of barnacle (Balanus amphitrite) cyprids settling in flow. Mar Biol 110:93-103

Mullineaux LS, Garland ED (1993) Larval recruitment in response to manipulated field flows. Mar Biol 116:667-683

Nishihira M (1967) Observations on the selection of algal substrata by hydrozoan larvae, Sertularella miurensis in nature. Bull Mar Biol Stn Asamushi 13:35-48

Nishihira M (1968) Experiments on the algal selection by the larvae of Coryne uchidai Stechow (Hydrozoa). Bull Mar Biol Stn Asamushi 13:83-89

Otto JJ (1978) The settlement of Haliclystus planulae. In: Chia FS, Rice ME (eds) Settlement and metamorphosis of marine invertebrate larvae. Elsevier, New York, p 13-22

Pawlik JR (1992) Chemical ecology of the settlement of benthic marine invertebrates. Oceanogr Mar Biol Annu Rev $30: 273-335$

Pearce CM. Scheibling RE (1990) Induction of settlement and metamorphosis in the sand dollar Echinarachnius parma: evidence for an adult-associated factor. Mar Biol 107 : $363-369$

Prenant M, Tessier G (1924) Notes éthologiques sur la faune marine sessile des environs de Roscoff Cirripèdes, Bryozoaires, Hydraires. Trav Stn Biol Roscoff 2:1-49

Pyefinch KA, Downing FS (1949) Notes on the general biology of Tubularia larynx Ellis \& Solander J Mar Biol Ass UK 28:21-43

Rittschof D, Branscomb ES, Costlow JD (1984) Settlement and behavior in relation to flow and surface in larval barna-

This article was submitted to the editor cles, Balanus amphitrite Darwin. J Exp Mar Biol Ecol 82: $131-146$

Rodriguez SR, Ojeda FP, Inestrosa NC (1993) Settlement of benthic marine invertebrates. Mar Ecol Prog Ser 97: 193-207

SAS Institute, Inc (1991) SAS/STAT user's guide, 603 edn. SAS Institute Inc, Cary, NC

Schmahl G (1985) Induction of stolon settlement in the scyphopolyps of Aurelia aurita (Cnidarıa, Scyphozoa, Semaneostomeae) by glycolipids of marine bacteria. Helgoländer Wiss Meeresunters 39:117-127

Sieburth JM, Conover JT (1965) Sargassum tannin, an antibiotic which retards fouling. Nature 208:52-53

Sokal RR, Rohlf FJ (1981) Biometry, 2nd edn. WH Freeman \& Co., New York

Sommer C (1990) Post-embryonic larval development and metamorphosis of the hydroid Eudendrium racemosum (Cavolini) (Hydrozoa, Cnidaria). Helgoländer Wiss Meeresunters 44:425-444

Stevenson RJ, Stoermer EF (1981) Quantitative differences between benthic algal communities along a depth gradient in Lake Michigan. J Phycol 17:36-39

Sutherland JP, Karlson RH (1977) Development and stability of the fouling community at Beaufort, North Carolina. Ecol Monogr 47:425-446

Svane I, Havenhand IN, Jorgensen A.J (1987) Effects of tissue extract of adults on metamorphosis in Ascidia mentula O.F. Müller and Ascidiella scabra (O.F. Müller). J Exp Mar Biol Ecol 110:171-181

Teitelbaum M (1966) Behavior and settling mechanism of planulae of Hydractinia echinata. Biol Bull Mar Biol Lab Woods Hole 131:410-411

Thorson G (1964) Light as an ecological factor in the dispersal and settlement of larvae of marine bottom invertebrates. Ophelia 1:67-208

Williams GB (1965) Observation on the behaviour of the planulae of Clava squamata. J Mar Biol Ass UK 45:257-273

Williams GB (1976) Aggregation during settlement as a factor in the establishment of coelenterate colonies. Ophelia 15:57-64

Young CM. Chia FS (1987) Abundance and distribution of pelagic larvae as influenced by predation, behavior, and hydrographic factors. In: Giese AC, Pearse JS, Pearse VB (eds) Reproduction of marine invertebrates. Blackwell, Palo Alto, CA, p 385-463

Yund PO, Cunningham CW, Buss LW (1987) Recruitment and postrecruitment interactions in a colonial hydroid. Ecology 68:971-982

Manuscript first received: August 7, 1995

Revised version accepted: April 12, 1996 